\title{
Performance Analysis (Physical) of Kalaburagi, Bidar and Yadgir Milk Union, Karnataka
}

\author{
Rashtrarakshak*, Jagrati B. Deshmanya, G. M. Hiremath, \\ Prabhuling Tevari, Vijaya B. Wali and Jagjiwan Ram
}

Department of Agricultural Economics, College of Agriculture, University of Agricultural

Sciences, Raichur, India

*Corresponding author

\section{A B S T R A C T}

Keywords

Number of members, Active DCS, Milk procurement, Growth rate, DCS (Dairy co-operative society)

Article Info

\section{Accepted:}

15 January 2021

Available Online:

10 February 2021
Dairying in India, in general, is closely interwoven as an integral part of agriculture, and it has also been recognized as an instrument of economic and social change especially of the weaker sections of the rural community. Karnataka Co-operative Milk Producers' Federation Limited (KMF) is the apex body for the dairy co-operative movement in Karnataka. It is the second largest dairy co-operative amongst the dairy cooperatives in the country. One of the core functions of the federation is marketing of milk and milk products. The brand "Nandini" is the household name for pure and fresh milk and milk products. KMF has 14 milk unions covering all the districts of the state which procure milk from Primary Dairy Cooperative Societies (DCS) and distribute milk to the consumers in various towns/cities/rural markets in Karnataka. The unions consist of 468, 868 and 433 dairy cooperative societies respectively with a membership of $27,085,72,001$ and 44,012 . Over a period of time, these unions are improving the socio economic conditions of the dairy entrepreneurs. Hence, through this paper an attempt has made to ananlyse the performance of milk union and selected the KBY milk union for the study. Further, highest procured DCS were selected in two zones and evaluated their physical and financial performance at the study period. The findings of the research revealed that the members of DCS enrolled in DCS had positively growth rate, 449 DCS were actively functioning. The CAGR was 2.08 and 2.05 significant at 5 per cent. Hence, it can be inferred that KBY milk union was found to be better performing in both physical and financial form last five years.

\section{Introduction}

The agriculture sector in India is undergoing rapid transformation. Increasing incomes, urbanization, exploding population, changing consumers' tastes and preferences, increased liberalization and integration with the global economy are some of the factors that are catalyzing this transformation. Livestock in general and dairying in 
particular is emerging as a driving force in the growth of agricultural sector of India. Dairying has been inherent in Indian culture for centuries. Dairying in India, in general, is closely interwoven as an integral part of agriculture, and it has also been recognized as an instrument of economic and social change especially of the weaker sections of the rural community. In India, coverage under Artificial Insemination (AI) in cattle and buffaloes are hardly 35 per cent. The main reason for low artificial insemination is semen straws. We require 160 million doses of semen straw against current availability of 81 million to reach reasonable level of AI. Presently about 4 million breed able buffaloes, 1.3 million breed able cross breed cattle and 6 million breed able indigenous cattle have never calved. Out of above population, at least 2 million buffaloes, 0.8 million cross breed and 3 million indigenous cattle should have additional number for calving by 2020. Age of buffaloes at puberty has to be reduced by 3-4 months by 2020 . At present, the puberty age of murrah buffaloes is about 33 months (Anonymous, 2020). India is presently the largest milk producing country with a production of about 100 million tonnes during 2006 (Anonymous, 2006). A growth rate of 4.5 per cent has been achieved by the dairy sector during the past decade as compared to a meager 2.0 per cent growth recorded by the agricultural sector as a whole. Growth in milk production has been caused by increase in per animal productivity, increase in population of milking cattle and buffaloes, increase in crossbred cattle and a marginal decline in the gross population of cattle. Dairy sector is highly livelihood intensive and provides supplementary income to 60-70 million households. Milk producer's cooperative societies have emerged as most viable institutions for milk procurement in rural areas. India has 1.13 lakh milk producers' cooperative societies with a membership of 1.23 crores. Milk procured by these societies was around 20.07 million litres per day during 2004-05 (Anonymous, 2006). Milk co-operatives are an integral part of the milk marketing and dairy development programme in India, White revolution popularly known as "Operation Flood" launched by the Government of India in collaboration with the world food programme of the United Nations in July 1970. It was the world's biggest dairy development programme. It transformed India from a milk deficient nation into the world's largest milk producer. Dairy farming is making a significant contribution to the national economy and socio-economic development in the country.

Karnataka Co-operative Milk Producers' Federation Limited (KMF) is the apex body for the dairy co-operative movement in Karnataka. It is the second largest dairy cooperative amongst the dairy cooperatives in the country. In South India it stands first in terms of procurement as well as sales. One of the core functions of the federation is marketing of milk and milk products. The brand "Nandini" is the household name for pure and fresh milk and milk products. KMF has 14 milk unions covering all the districts of the state which procure milk from Primary Dairy Cooperative Societies (DCS) and distribute milk to the consumers in various towns/cities/rural markets in Karnataka. The unions consist of 468, 868 and 433 dairy cooperative societies respectively with a membership of 27,085, 72,001 and 44,012. Over a period of time, these unions are improving the socio economic conditions of the dairy entrepreneurs by providing additional employment opportunities and enhancing the income of family. Despite the increase in production, a demand-supply gap has become imminent in the dairy industry due to the changing consumption habits, dynamic demographic patterns, and the rapid 
urbanization of rural India. Hence, through this paper an attempt has made to analyse the performance of milk union.

\section{Materials and Methods}

\section{Description of study area}

NEK region comprising of six districts, viz., Bidar, Ballari, Koppal, Kalaburagi, Raichur and Yadgir lag behind and has very poor per capita income. The NEK has been a dry and backward region in terms of agricultural development. Besides, the rate of public and private investments in this region has been low and hence these reasons continue to remain agriculturally backward. KalaburagiBidar and Yadgir Co-operative Milk Producers Societies Union Limited abbreviated as KBY. More than 344 functioning DCSs covering 13 out of 15 taluks in Kalaburagi, Bidar and Yadgir districts. There were, 15 bulk milk coolers, 113 automatic milk collection and 1 community Milking Parlours in the union. Hence, KBY milk union was selected for the study.

\section{Sampling procedure}

The KBY Milk Producers Societies Union was selected for the study as it covers three districts of North Eastern region of Karnataka. Further, the milk union was divided in two major zones namely North Eastern Dry Zone and North Eastern Transitional Zone, considered as Zone-I and Zone-II respectively. From each Zone, six dairy co-operative societies were selected based on highest milk procurement per day. Zone-I consists of Pattan (1138 lit./day), Mallabad (980 lit./day), Kognoor (764 lit./day), Niloor (738 lit./day), Hirapur (694 lit./day) and Melakunda. K. (578 lit./day) DCS villages. Further, Zone-II consists of Huliyur (1379 lit./day), Bhoosnoor (1376 lit./day), Sarsamba (944 lit./day), Tadol
(846 lit./day), Dudknal (763 lit./day) and Khazoori (738 lit./day) DCS villages.

\section{Data collection}

The secondary data on several aspects of the activities of the milk unions were collected from KBY Milk Producers Societies Union Limited and DCS under Zone-I and Zone-II depending upon the availability of the required information.

\section{Analytical tools}

\section{Compound growth rate analysis}

Among the various physical and financial indicators considered for the performance study, the compound growth rates were estimated for physical and financial indicators of the KBY milk unions.

The linear, log-linear, exponential and power functions are some of the important functional forms employed to study the growth rates. Different functional forms were tried in the past for working out the growth rates. Some of the important forms tried were the linear growth model $(\mathrm{Y}=\mathrm{a}+\mathrm{bt})$, exponential function $\left(Y=a b^{t}\right)$ and quadratic function $(Y=$ $\left.a+b t+c t^{2}\right)$. However, it was found that the exponential form of the function $Y_{t}=a b^{t}$ is the better and most frequently used one. In the present study, compound growth rates in physical and financial indicators were estimated by specifying the following relationship.

$Y_{t}=a b^{t} U_{t} \ldots(1.1)$

where,

$\mathrm{Y}_{\mathrm{t}}=$ indicator/variable in the year ${ }^{6} \mathrm{t}^{\prime}$

$\mathrm{t}=$ year which takes value $1,2, \ldots \ldots \mathrm{n}$ 
$\mathrm{U}_{\mathrm{t}}=$ disturbance term in year' $\mathrm{t}^{\prime} \mathrm{a}=$ constant

$\mathrm{b}=$ regression co-efficient

'a' and ' $\mathrm{b}$ ' are parameters to be estimated.

The equation (1.1) was transformed into loglinear form and written as:

$\log \mathrm{Y}=\log \mathrm{a}+\mathrm{t} \log \mathrm{b}+\log \mathrm{U}_{\mathrm{t}} \ldots(1.2)$

Equation (1.2) was estimated by using ordinary least square (OLS) technique.

Compound growth rate $(\mathrm{g})$ was then estimated by the identity given in equation (1.3).

$\mathrm{g}=(\mathrm{b}-1) \times 100 \ldots(1.3)$

where,

$\mathrm{g}=$ estimated compound growth rate in per cent per annum.

$b=$ antilog of $\log b$

\section{Results and Discussion}

\section{Physical performance of KBY milk union}

Physical performance of KBY Milk Producers Union was assessed for the twenty years from 1998-99 to 2018-19. The performance was assessed for the interval of five year. The indicators used for the performance assessment were number of milk union, members, number of DCS, number of active DCS, milk produced per annum, number of animals artificial insemination given, number of animals treated, training programme conducted by milk union, cattle feed sold by union and area under fodder crop cultivated by the union were presented in Table 1 and Table 2. From the table it is revealed that the total number of members of the union were increased from 75678 (1998-99) to 139875
(2018-19), the number of total DCS increased from 245 to 879 of which 449 were actively functioning and remaining 430 were closed. The 430 milk unions were under loss hence they were closed. The milk procurement of the union was also increased from 18,961 to 63,555 litres per annum. It is due to the better performance of active DCS. The milk union also provided the artificial insemination service, the number of artificial insemination animals increased over the years from 8,092 (1998-99) to 12,441 (2018-19). The milk union gave the first aid treatment to the diseased animals.

The number of treated animals were increased from 82,861 (1998-99) to $1,02,765$ (2018-19) due to increase in the members of DCS. It was interesting to note that many training programme were conducted by the milk union to create awareness among the people to do scientific dairying. 876 training programme were conducted by milk union during the year 2018-19.

Similarly, cattle feed sold by the union was $783 \mathrm{kgs}$ and the area under fodder crop cultivated was 89.63 hectare during the year 2018-19. From the table, it was also observed the growth rates of number of DCS members, total DCS, active functioning DCS and quantity of milk procurement per annum was $2.08,2.05,2.04$ significant at 1 per cent and 5.17 significant at 5 per cent level of significance, respectively, indicating better performance of the union.

The artificial insemination (A.I) service was also extended with a significant growth rate of 4.74 for inseminating animals to increase milk yield. The first aid service of animal had positive growth rate of 2.89 , indicating that increase of membership of the DCS had increased the first aid services. Similarly, the cattle feed sold by union had a growth rate of 1.47 . 
Table.1 Physical performance indicators of Kalaburgi milk union (1999-2019)

\begin{tabular}{|c|c|c|c|c|c|c|c|c|c|}
\hline Year & Members & New DCS & Active DCS & Milk procured & $\begin{array}{c}\text { A.I } \\
\text { done } \\
\text { (no.) }\end{array}$ & $\begin{array}{c}\text { Animal } \\
\text { treated } \\
\text { (no.) }\end{array}$ & $\begin{array}{c}\text { Trainings } \\
\text { (no.) }\end{array}$ & $\begin{array}{l}\text { Cattle feed } \\
\text { sold (Kgs) }\end{array}$ & $\begin{array}{l}\text { Area under } \\
\text { fodder } \\
\text { crop (ha.) }\end{array}$ \\
\hline 1998-99 & 75678 & 19 & 12 & 18961 & 8092 & 82861 & 762 & 745 & 146.6 \\
\hline 1999-00 & 89087 & 4 & 4 & 19402 & 11034 & 78198 & 893 & 678 & 288.77 \\
\hline 2000-01 & 93450 & 2 & 2 & 18370 & 12364 & 38663 & 461 & 583 & 301.63 \\
\hline 2001-02 & 96115 & 3 & 2 & 18857 & 14443 & 88774 & 347 & 600 & 244.21 \\
\hline 2002-03 & 98678 & 4 & 2 & 19083 & 18129 & 86845 & 771 & 756 & 192.63 \\
\hline 2003-04 & 100565 & 10 & 5 & 18089 & 114787 & 94486 & 705 & 455 & 98.18 \\
\hline 2004-05 & 101675 & 8 & 6 & 21344 & 8976 & 48501 & 755 & 682 & 67.94 \\
\hline 2005-06 & 110245 & 13 & 9 & 23954 & 9110 & 86469 & 805 & 755 & 75.17 \\
\hline 2006-07 & 118219 & 10 & 4 & 24278 & 14016 & 37350 & 857 & 654 & 180.63 \\
\hline 2007-08 & 124114 & 17 & 7 & 21652 & 10768 & 49514 & 921 & 631 & 110.23 \\
\hline 2008-09 & 124764 & 2 & 2 & 17181 & 14201 & 82259 & 897 & 711 & 127.38 \\
\hline 2009-10 & 125614 & 7 & 5 & 17954 & 11397 & 38883 & 891 & 587 & 199.46 \\
\hline 2010-11 & 127814 & 15 & 11 & 30062 & 11448 & 86334 & 813 & 676 & 152.35 \\
\hline 2011-12 & 128914 & 33 & 11 & 46765 & 12013 & 59760 & 902 & 632 & 127.36 \\
\hline 2012-13 & 129114 & 38 & 17 & 60786 & 13014 & 101993 & 892 & 570 & 141.22 \\
\hline 2013-14 & 136310 & 8 & 2 & 56105 & 12168 & 83309 & 842 & 672 & 132.26 \\
\hline 2014-15 & 137403 & 21 & 5 & 55103 & 11491 & 62817 & 887 & 647 & 100.42 \\
\hline 2015-16 & 137955 & 58 & 18 & 54966 & 12642 & 53924 & 801 & 605 & 98.67 \\
\hline 2016-17 & 138176 & 21 & 14 & 51032 & 13963 & 81011 & 926 & 774 & 101.58 \\
\hline 2017-18 & 139415 & 189 & 100 & 51123 & 10578 & 110602 & 863 & 634 & 103.45 \\
\hline 2018-19 & 139875 & 41 & 41 & 63555 & 12441 & 102765 & 876 & 783 & 89.63 \\
\hline
\end{tabular}


Table.2 Physical performance indicators of KBY milk union over the decades

\begin{tabular}{|c|c|c|c|c|c|c|c|c|c|}
\hline Years & $\begin{array}{c}\text { Members } \\
\text { (no.) }\end{array}$ & $\begin{array}{c}\text { Total } \\
\text { DCS } \\
\text { (no.) }\end{array}$ & $\begin{array}{c}\text { Active } \\
\text { DCS } \\
\text { (no.) }\end{array}$ & $\begin{array}{c}\text { Milk } \\
\text { procured } \\
\text { (liters/annum) }\end{array}$ & $\begin{array}{c}\text { A.I } \\
\text { Done } \\
\text { (no.) }\end{array}$ & $\begin{array}{c}\text { Animals } \\
\text { treated (no.) }\end{array}$ & $\begin{array}{c}\text { Trainings } \\
\text { conducted } \\
\text { (no.) }\end{array}$ & $\begin{array}{c}\text { Cattle } \\
\text { feed } \\
\text { sold } \\
\text { (Kgs) }\end{array}$ & $\begin{array}{c}\text { Area } \\
\text { under } \\
\text { fodder } \\
\text { crop (ha.) }\end{array}$ \\
\hline $\mathbf{1 9 9 8 - 9 9}$ & 75678 & 245 & 150 & 18961 & 8092 & 82861 & 762 & 745 & 146.60 \\
\hline $\mathbf{2 0 0 3 - 0 4}$ & 100565 & 265 & 160 & 18089 & 14787 & 94486 & 705 & 455 & 98.18 \\
\hline $\mathbf{2 0 0 8 - 0 9}$ & 124764 & 339 & 190 & 17181 & 14201 & 82259 & 897 & 711 & 127.38 \\
\hline $\mathbf{2 0 1 3 - 1 4}$ & 136310 & 539 & 262 & 56105 & 12168 & 83309 & 842 & 672 & 132.26 \\
\hline $\mathbf{2 0 1 8 - 1 9}$ & 139875 & 879 & 449 & 63555 & 12441 & 102765 & 876 & 783 & 89.63 \\
\hline CAGR\% & $\mathbf{2 . 0 8}^{*}$ & $\mathbf{2 . 0 5}^{* *}$ & $\mathbf{2 . 0 4} *$ & $\mathbf{5 . 1 7} * *$ & $\mathbf{0 . 7 5}$ & $\mathbf{4 . 7 4}^{*}$ & $\mathbf{2 . 8 9}$ & $\mathbf{1 . 4 7}^{*}$ & $\mathbf{- 5 . 3 8 ^ { * }}$ \\
\hline
\end{tabular}

Note: DCS= Dairy co-operative society

A.I $=$ Artificial Insemination

** Significant at 1 per cent, $*$ Significant at 5 per cent

Table.3 Performance of sample DCS of Zone-I and Zone-II during the year 2018-2019

\begin{tabular}{|c|c|c|c|c|c|c|c|}
\hline DCS & $\begin{array}{c}\text { Members } \\
\text { (no.) }\end{array}$ & $\begin{array}{c}\text { AI done } \\
\text { (no.) }\end{array}$ & $\begin{array}{c}\text { Animal } \\
\text { treated } \\
\text { (no.) }\end{array}$ & $\begin{array}{c}\text { Trainings } \\
\text { conducted } \\
\text { (no.) }\end{array}$ & $\begin{array}{c}\text { Cattle } \\
\text { feed sold } \\
\text { (Kgs) }\end{array}$ & $\begin{array}{c}\text { Milk } \\
\text { procured } \\
\text { (liters/day) }\end{array}$ & $\begin{array}{c}\text { Milk } \\
\text { value } \\
(\text { ) }\end{array}$ \\
\hline Pattan & 150 & 230 & 560 & 4 & 600 & 1138 & 23898 \\
\hline Mallabad & 150 & 180 & 350 & 5 & 650 & 980 & 20580 \\
\hline Kognoor & 100 & 200 & 400 & 2 & 400 & 764 & 16044 \\
\hline Niloor & 140 & 150 & 428 & 3 & 560 & 738 & 15498 \\
\hline Hirapur & 300 & 150 & 365 & 2 & 1250 & 694 & 14574 \\
\hline Melkunda (k) & 150 & 200 & 253 & 3 & 425 & 578 & 12138 \\
\hline Total (A) & $\mathbf{9 9 0}$ & $\mathbf{1 1 1 0}$ & $\mathbf{2 3 5 6}$ & $\mathbf{1 9}$ & $\mathbf{3 8 8 5}$ & $\mathbf{4 8 9 2}$ & $\mathbf{1 0 2 7 3 2}$ \\
\hline & & & $\mathbf{Z n n e - I I}$ & & & & \\
\hline Huliyur & 250 & 150 & 453 & 6 & 1000 & 1379 & 28959 \\
\hline Bhoosnoor & 180 & 260 & 590 & 2 & 720 & 1376 & 28896 \\
\hline Saramba & 100 & 200 & 650 & 4 & 400 & 944 & 19824 \\
\hline Tadol & 120 & 170 & 450 & 6 & 560 & 846 & 17766 \\
\hline Dudknal & 200 & 300 & 683 & 2 & 800 & 763 & 16023 \\
\hline Khazoori & 100 & 250 & 370 & 2 & 600 & 738 & 15498 \\
\hline Total (B) & $\mathbf{9 5 0}$ & $\mathbf{1 3 3 0}$ & $\mathbf{3 1 9 6}$ & $\mathbf{2 2}$ & $\mathbf{4 0 8 0}$ & $\mathbf{6 0 4 6}$ & $\mathbf{1 2 6 9 6 6}$ \\
\hline Difference (B $-\mathbf{A})$ & $\mathbf{4 0}$ & $\mathbf{2 2 0}$ & $\mathbf{8 4 0}$ & $\mathbf{3}$ & $\mathbf{1 9 5}$ & $\mathbf{1 1 5 4}$ & $\mathbf{2 4 2 3 4}$ \\
\hline t-value & - & - & - & - & $\mathbf{2 . 0 6 *}$ & $\mathbf{3 . 0 6 * *}$ & $\mathbf{2 . 1 1}$ \\
\hline
\end{tabular}

Note: ** Significant at 1 per cent, $*$ Significant at 5 per cent

Performance of the Dairy co-operative and Zone-II were assessed, the findings are societies (DCS) presented in the Table 3 . The table revealed that the members enrollment in Zone-I (990)

The performance of the sample DCS of Zone-I was more than Zone-II (950), but the milk 
procurement of Zone-II (6046 lit/day) was significantly higher than Zone-I (4892 lit/day).

The milk value of Zone-II DCS was `126966 and significantly higher than Zone-I `1,02,732, indicated that the financial performance of Zone-II DCS was better than Zone-I DCS. The number of artificial insemination done, animal treated, training programme conducted and cattle feed sold by DCS were comparatively higher in Zone-II indicated that, the physical indicators also performed better in Zone-II than Zone-I. This may be due to higher livestock population that results in higher milk procurement and milk value in Zone-II than Zone-I. From the above findings it can be concluded that, the KBY milk union was performing better from last decade. Indicating the positive growth of the union and performance of DCS functioned under KBY milk union and found to be better performance of Zone-II DCS than Zone-I DCS. Hence, it can be suggested to the union give more attention towards Zone-I area DCS for greater profit of the union.

\section{References}

Anonymous, 2006, Basic animal husbandry statistics report, Department of Animal Husbandry and Dairying, pp 125-196.

Anonymous, 2020, Annu. Rep. (2019-20). Dept. of Anim. Hus. \&Vet. Sci. Coimbatore, p 16.

Anonymous, 2018, Annu. Rep. (2018-19). Kalburgi milk union. KMF. p 110.

Patil, S. S., 1999, Economic evaluation of Gulbarga milk union, Karnataka state. Ph. D. Thesis, Univ. Agric. Sci., Dharwad, Karnataka, (India).

\section{How to cite this article:}

Rashtrarakshak, Jagrati B. Deshmanya, G. M. Hiremath, Prabhuling Tevari, Vijaya B. Wali and Jagjiwan Ram. 2021. Performance Analysis (Physical) of Kalaburagi, Bidar and Yadgir Milk Union, Karnataka. Int.J.Curr.Microbiol.App.Sci. 10(02): 1725-1732.

doi: https://doi.org/10.20546/ijcmas.2021.1002.203 